\title{
C-reactive protein and complement as acute phase reactants in common carp Cyprinus carpio during CyHV-3 infection
}

\author{
Nicolas Pionnier ${ }^{1}$, Mikołaj Adamek ${ }^{2}$, Joanna J. Miest ${ }^{1}$, Sarah J. Harris ${ }^{1,2}$, \\ Marek Matras ${ }^{3}$, Krzysztof Ł. Rakus ${ }^{4,5}$, Ilgiz Irnazarow ${ }^{4}$, Dave Hoole ${ }^{1, *}$ \\ ${ }^{1}$ Institute of Science and Technology in Medicine, School of Life Sciences, Keele University, ST5 5BG Keele, UK \\ ${ }^{2}$ Fish Diseases Research Unit, Centre for Infection Medicine, University of Veterinary Medicine in Hanover, Bünteweg 17, \\ 30559 Hanover, Germany \\ ${ }^{3}$ Laboratory of Fish Diseases, National Veterinary Research Institute, Partyzantów 57, 24-100 Puławy, Poland \\ ${ }^{4}$ Polish Academy of Sciences, Institute of Ichthyobiology \& Aquaculture in Gołysz, Kalinowa 2, 43-520 Chybie, Poland \\ ${ }^{5}$ Present address: Immunology-Vaccinology (B43b), Department of Infectious and Parasitic Diseases (B43b), \\ Faculty of Veterinary Medicine, University of Liège, 4000 Liège, Belgium
}

\begin{abstract}
Cyprinid herpesvirus 3 (CyHV-3) is the aetiological agent of a highly virulent and lethal disease of common carp Cyprinus carpio and its ornamental koi varieties. However, specific knowledge about immune mechanisms behind the infection process is very limited. We aimed to evaluate the effect of the CyHV-3 infection on the profile of 2 major components of the common carp immune acute phase response: the C-reactive protein (CRP) and the complement system. Common carp were infected with CyHV-3 by bath immersion. Fish were sampled before the infection and at $6,12,24,72,120$ and $336 \mathrm{~h}$ post-infection for serum and head kidney, liver, gill and spleen tissues. CRP levels and complement activity were determined from the serum, whereas CRP- and complement-related genes (crp1, crp2, c1rs, bf/c2, c3, masp2) expression profiles were analysed in the tissues by quantitative PCR. Both CRP levels and complement activity increased significantly up to 10- and 3-fold, respectively, in the serum of infected fish during the challenge. Analysis revealed distinct organ- and time-dependent expression profile patterns for all selected genes. These results suggest that CRP and complement behave as acute phase reactants to CyHV-3 infection in common carp with an organ- and time-dependent response.
\end{abstract}

KEY WORDS: CRP · Complement · Cyprinid herpesvirus $3 \cdot \mathrm{KHV} \cdot$ Koi herpesvirus · Carp · Biomarker

\section{INTRODUCTION}

Although viral pathogens and associated diseases are less common in aquaculture than bacterial, parasitic and fungal diseases, some viruses cause major economic losses resulting in high mortality and/or morbidity rates in a very short period of time postinfection (Crane \& Hyatt 2011). In the late 1990s, a highly contagious and virulent disease began to cause significant mortality of common carp Cyprinus carpio and its ornamental koi varieties C. carpio koi worldwide (Bretzinger et al. 1999, Hedrick et al. 2000, Haenen et al. 2004, Pokorova et al. 2005). The causative agent of the disease was cyprinid herpesvirus 3 (CyHV-3), also known as koi herpesvirus (KHV) or carp interstitial nephritis and gill necrosis virus (CNGV). CyHV-3, a member of the genus Cyprinivirus, family Alloherpesviridae, order Herpes- 
virales (Davison et al. 2009), has a genome comprising $295 \mathrm{~kb}$, linear, double-stranded DNA predicted to contain 155 potential protein-coding open reading frames (ORFs) (Davison et al. 2013). The genome is enclosed within an icosahedral capsid surrounded by a tegument and a host-derived lipid envelope, which contains virus glycoproteins (Michel et al. 2010). The mode of entrance of the virion into a fish has been demonstrated to occur primarily via the skin (Costes et al. 2009, Raj et al. 2011) and the pharyngeal periodontal mucosa (Fournier et al. 2012), although the gills and the gut may also serve as other possible infection routes (Dishon et al. 2005). The mortality rate can be as high as 80 to $100 \%$ in susceptible populations (Hedrick et al. 2000), with death occurring 6 to 7 d post exposure (Dixon et al. 2009, Rakus et al. 2009). External and internal disease symptoms have been well characterised and include severe gill lesions with the appearance of necrosis, bleeding gills, sunken eyes, and pale skin patches (Pokorova et al. 2005), as well as abnormal adhesions in the body cavity and a mottled appearance of internal organs (Hedrick et al. 2000, Goodwin 2003, Perelberg et al. 2003). Infection with CyHV-3 leads to severe leucocytosis shortly after infection (Negenborn 2009), and recent microarray and quantitative (qPCR) analyses have shown up-regulation of several immune-related genes indicating increased inflammation, type I IFN and T cell responses (Rakus et al. 2012, Adamek et al. 2013). Furthermore, fish were shown to develop protective antibodies to CyHV-3 after $40 \mathrm{~d}$ of exposure (Adkison et al. 2005). However, some critical aspects of the carp innate immune response against CyHV-3 such as the acute phase proteins have not been extensively analysed and yet may provide protection during the very first days of infection when an adaptive immune response against CyHV-3 may not be functional. For example, Rakus et al. (2012) noted a potential role of classical complement activation in the resistance of carp against this virus.

The acute phase response (APR) is an important constituent of the host's innate immune defence in response to injury, tissue trauma and pathogen invasion. This systemic response consists of a series of specific physiological reactions that involve metabolic changes in the host (Bayne \& Gerwick 2001). Among the different plasma proteins mobilised during an APR, the complement system and C-reactive protein (CRP) play a significant role during bacterial infections (MacCarthy et al. 2008, Dumrongphol et al. 2009, Mohanty \& Sahoo 2010, Pionnier et al. 2013). However, during viral infections, APRs are usually lower (Gruys et al. 2005), and CRP serum levels have often been exploited to discriminate between viral and bacterial infections (Costalonga et al. 2009). Nevertheless, when severe cellular destruction occurs as a result of virus spread through the organism, a full APR can be observed (Gruys et al. 2005). CRP, an evolutionary conserved protein found in the body fluids of both invertebrates and vertebrates, is commonly associated with the APR (Pepys et al. 1978) and has been proposed as a biomarker for infection and/or health status in cultured carp (Ramos \& Smith 1978, MacCarthy et al. 2008). Interestingly, recent studies performed in healthy carp or fish infected with Aeromonas salmonicida also revealed a widespread constitutive expression of CRP-related genes with differential expression in the gut, liver and head kidney, suggesting different biological activities of the related isoforms (Falco et al. 2012, Pionnier et al. 2013). Serum CRP levels increase by up to 6-fold in common carp within $40 \mathrm{~h}$ of infection with A. hydrophila (MacCarthy et al. 2008) and up to 18-fold within 2 to $4 \mathrm{~d}$ in channel catfish Ictalurus punctatus exposed to turpentine (Szalai et al. 1994). Complement, another essential component of the fish APR, is a cascade comprised of numerous membrane-bound and soluble proteins leading to the formation of a membrane attack complex which destroys the pathogen (Nakao et al. 2011). Complement activation through the classical and/or alternative pathways is commonly evaluated in the serum of infected fish. Recent studies have concentrated on complement-related genes in fish during bacterial (Dumrongphol et al. 2009, Mohanty \& Sahoo 2010), viral (Yasuike et al. 2007, Encinas et al. 2010, Rakus et al. 2012) or parasitic (Gonzalez et al. 2007, Forlenza et al. 2009) infections. These investigations have revealed extra-hepatic expression of complement components and suggest an important role of complement in the regulation of local immune responses (Forlenza et al. 2009, Nakao et al. 2011).

The aim of the present study was to determine the association between the APR proteins of common carp and viral infection. Building upon the preliminary investigations of Rakus et al. (2012) on carp complement activation, we report the role of the APR in common carp during a CyHV-3 infection. The expression profile of 2 carp CRP-like genes (crp1 and crp2), recently described by Falco et al. (2012), and several carp complement component genes (c1rs, $b f / c 2, c 3$ and masp2), described by Forlenza et al. (2009), were analysed in the liver, head kidney, spleen and gill of CyHV-3- or sham-infected carp as markers of the APR. 


\section{MATERIALS AND METHODS}

\section{Experimental animals}

Common carp Cyprinus carpio from the Polish $\mathrm{K}$ line (Białowa̧s et al. 2008) were kept at $21 \pm 1^{\circ} \mathrm{C}$ in UV treated re-circulating systems under a 12:12 h light:dark cycle at the Institute of Ichthyobiology and Aquaculture in Golysz, Poland. Fish were fed daily with commercial carp pellets (Aller Aqua) at 3 to $5 \%$ body weight. Carp $(\mathrm{n}=70)$ with an average weight of $120 \mathrm{~g}$ were transported to the Laboratory of Fish Disease, National Veterinary Research Institute, Pulawy, Poland, and allowed to acclimatise in $800 \mathrm{l}$ tanks at $21 \pm 1^{\circ} \mathrm{C}$ for $4 \mathrm{wk}$. Feeding was carried out with commercial carp pellets at $3 \%$ body weight per day.

\section{Virus preparation}

CyHV-3 was prepared as described by Rakus et al. (2012). Briefly, Cyprinus carpio brain (CCB) cells (Neukirch et al. 1999), cultured in minimum essential medium, were inoculated with $\mathrm{CyHV}-3$ virus isolated in the Laboratory of Fish Disease, National Veterinary Research Institute in Pulawy, Poland, from infected common carp in 2005 (passage no. 4). The medium from infected cells, which included the virus, was harvested and used for fish infection. The virus suspension titre, given as tissue culture infective dose $\left(\mathrm{TCID}_{50} \mathrm{ml}^{-1}\right)$, was determined by the method of Reed \& Muench (1938) at $8 \times 10^{4} \mathrm{TCID}_{50} \mathrm{ml}^{-1}$.

\section{CyHV-3 challenge and fish sampling}

Carp used within this trial were from the same cohort as described by Rakus et al. (2012). Carp ( $\mathrm{n}=$ 35) were infected with CyHV-3 by bath immersion challenge. Fish were bathed for $1 \mathrm{~h}$ at $22^{\circ} \mathrm{C}$ in small plastic containers containing $15 \mathrm{l}$ of aquarium water and the virus suspension (320 TCID ${ }_{50} \mathrm{ml}^{-1}$ in the final volume of water). In addition, 35 carp were shaminfected following the same protocol with the difference that medium was harvested from uninfected CCB cultures. Control and infected fish were returned to their respective tanks, and 5 carp from both groups were sampled at 6, 12, 24, 72, 120 and $336 \mathrm{~h}$ post-infection (hpi). Five additional fish from the control group were sampled for time point 0, i.e. just before the exposure to the virus. Carp were lethally anaesthetized by submersion in $0.5 \mathrm{~g} \mathrm{l}^{-1}$ tri- caine (Sigma); blood was obtained from the caudal vein, allowed to clot overnight at $4^{\circ} \mathrm{C}$, centrifuged $\left(2500 \times g, 10 \mathrm{~min}\right.$ at $\left.4^{\circ} \mathrm{C}\right)$ and the serum stored at $-80^{\circ} \mathrm{C}$. Liver, head kidney, spleen and gills were removed at 24, 72, 120 and $336 \mathrm{hpi}$ and stored in RNAlater (Qiagen) at $-80^{\circ} \mathrm{C}$. Tissues were selected for the following reasons: the liver as the main production site for CRP, the head kidney and the spleen as primary immune organs, and the gills as one of the organs prone to infection. Samples (organs and serum) were sent on ice to Keele University (UK) for further analysis.

\section{Quantification of free-phase carp CRP (CCRP) in serum}

Free-phase CRP from carp serum (cCRP) was quantified (MacCarthy et al. 2008, Pionnier et al. 2013) with a competitive enzyme-linked immunosorbent assay (ELISA) using CRP extracted and purified from healthy carp serum with a 2-step affinity chromatography procedure (Cartwright et al. 2004, MacCarthy et al. 2008). Briefly, high-density lipoprotein complexes containing apolipoprotein A-I, a major contaminant in the affinity isolation of carp CRP (Cartwright et al. 2004) were removed from the serum before the collection of purified free-phase CCRP which was stored at $4^{\circ} \mathrm{C}$ in a calcium buffer (10 $\mathrm{mM} \mathrm{CaCl}_{2}, 50 \mathrm{mM}$ Tris base, $15 \mathrm{mM} \mathrm{NaCl}_{2}, \mathrm{pH}$ ) until required.

Determination of CRP levels in the serum of experimental and control fish was carried out using a competitive ELISA. Briefly, individual wells of a high-binding capacity 96-well plate (Corning) were coated with $0.2 \mu \mathrm{g}$ of cCRP diluted in coating buffer (15 mM sodium carbonate, $35 \mathrm{mM}$ sodium bicarbonate, $\mathrm{pH} 9.6$ ) and incubated for $20 \mathrm{~h}$ at $4^{\circ} \mathrm{C}$. Unbound CCRP was removed by washing 3 times with a PBS-T buffer (PBS with $0.2 \%$ Tween-20), and any remaining binding sites were blocked by incubating at $37^{\circ} \mathrm{C}$ for 30 min in PBS containing $5 \%$ of dried milk powder (Marvel). Any excess of blocking agent was removed by washing 3 times with PBS-T. Carp serum (diluted 1:10 in PBS) was incubated with $160 \mu \mathrm{g} \mathrm{ul}^{-1}$ of rabbit anti-native cCRP IgG (produced by Cartwright et al. 2004) for $30 \mathrm{~min}$ at $20^{\circ} \mathrm{C}$. A standard curve was produced by replacing carp serum with purified free phase cCRP serially diluted in PBS (0 to $0.5 \mu \mathrm{g} \mathrm{ml}^{-1}$ ). After incubation with either carp serum or standards, $100 \mu \mathrm{l}$ of the treated rabbit anti-cCRP IgG solution was applied to the cCRP-coated wells and incubated for $1 \mathrm{~h}$ at $37^{\circ} \mathrm{C}$. Excess antibody was 
removed by washing 3 times with PBS-T, and $100 \mu \mathrm{l}$ of the secondary antibody, a goat anti-rabbit IgG peroxidase conjugate (Sigma, dilution 1:8000 in PBS), was applied to the wells and incubated for $1 \mathrm{~h}$ at $37^{\circ} \mathrm{C}$. After washing 5 more times with PBS-T, $100 \mu \mathrm{l}$ of $o$-phenylenediamine dihydrochloride (Sigma) were added to each well. The plate was incubated for $1 \mathrm{~h}$ at $37^{\circ} \mathrm{C}$ in the dark before adding $25 \mu \mathrm{l}$ of $2.5 \mathrm{M} \mathrm{HCl}$ to stop the enzymatic reaction. The optical density (OD) of each sample was read at $492 \mathrm{~nm}$ (Labsystems Multiskan MS plate reader). The cCRP concentration of the individual serum samples was determined with the GraphPad Prism v5 software by comparison between the sample absorbance value and those from the standard curve for which the free phase cCRP concentration is known.

\section{Alternative complement pathway activity assay in carp serum}

Serum alternative complement pathway (ACP) activity was analysed according to previously described methods (Matsuyama et al. 1988, Yano et al. 1988, Yano 1996, Selvaraj et al. 2005, 2006) with slight modifications as reported by Pionnier et al. (2013). Briefly, sheep red blood cells (SRBC; TCS Biosciences) were washed with $0.85 \%$ saline solution and resuspended in gelatin veronal buffer $(\mathrm{GVB}$; $0.1 \%$ gelatin, $250 \mathrm{mM} \mathrm{NaCl}, 50 \mathrm{mM}$ barbitone, $40 \mathrm{mM}$ sodium barbitone, $10 \mathrm{mM} \mathrm{MgCl}_{2}, 2 \mathrm{mM}$ $\mathrm{CaCl}_{2}$ all from Sigma), and a standard working concentration of $8 \times 10^{6} \mathrm{SRBC} \mathrm{ml}^{-1}$ was prepared. Carp serum was subjected to serial dilution (from $7 \%$ to $0.5 \%)$ and incubated for $1 \mathrm{~h}$ at $20^{\circ} \mathrm{C}(0.1$ to $15 \mu \mathrm{l}$ of serum, $100 \mu \mathrm{l} 10 \mathrm{mN}$ EGTA-GVB, $100 \mu \mathrm{l}$ SRBC). For each dilution, a positive control reflecting 100\% haemolysis was also analysed ( 0.1 to $15 \mu \mathrm{l}$ of serum, $100 \mu \mathrm{l}$ distilled water, $100 \mu \mathrm{l}$ SRBC), and a negative control in which sera were subjected to heat inactivation $\left(56^{\circ} \mathrm{C}\right.$ for $\left.30 \mathrm{~min}\right)$ was also included.

Samples were then subjected to centrifugation at $400 \times g\left(5 \mathrm{~min}\right.$ at $\left.4^{\circ} \mathrm{C}\right)$ and kept on ice at $4^{\circ} \mathrm{C}$ in order to stop the lytic reaction. Supernatant $(200 \mu \mathrm{l})$ was transferred to a 96-well plate, and the haemoglobin release was measured by OD reading at $410 \mathrm{~nm}$ (Labsystems Multiskan MS plate reader). The rate of haemolysis was calculated for each serum dilution as the OD value for the sample test divided by the OD value for the positive control. Graphs were built with GraphPad Prism v5 software by plotting the log(dilution) against the $\log$ (rate of haemolysis); the $\mathrm{ACH}_{50}$ (in $\mathrm{ACH}_{50}$ units $\mathrm{ml}^{-1}$ ), corresponding to the serum dilution giving $50 \%$ SRBC haemolysis, was determined from the graph.

\section{Quantification of CyHV-3 DNA}

Virus DNA quantification was performed using real-time TaqMan qPCR (Gilad et al. 2004). DNA was isolated from $25 \mathrm{mg}$ of liver, spleen and gill tissues after mechanical lysis by means of a QIAgen Tissuelyser II (Qiagen) using the QIAamp DNA Mini Kit (Qiagen) following the manufacturer's instructions. After isolation, the quantity of DNA obtained was evaluated with a Nanodrop ND-1000 spectrophotometer (Thermo Scientific). Real-time TaqMan qPCR was performed to amplify a fragment of the CyHV-3 ORF 89 and ORF 90 genes (Table 1) by the use of the KHV86F and KHV-163R primers and the KHV-109P probe (Table 1). The PCR reaction mix contained $1 \times$ master mix (Maxima Probe qPCR Kit, Fermentas), $800 \mathrm{nM}$ of each primer and $100 \mathrm{nM}$ of fluorescent probe. The reaction was performed using a Stratagene Mx 3005P thermocycler (Agilent). In order to quantify virus genome copies, a recombinant plasmid to be used as standard was obtained by ligating a PCR product amplified with the primers KHV-86F and KHV-163R into the pGEM-T Easy vector (Promega). The PCR was performed using high fidelity polymerase (Advantage 2 PCR kit, Clontech), and the plasmids were propagated in JM109 competent Escherichia coli (Promega). Plasmids were isolated with the GeneJET ${ }^{\mathrm{TM}}$ Plasmid Miniprep Kit (Fermentas), and a standard curve from $10^{0}$ to $10^{8}$ gene copies was prepared and used for quantification of the copy numbers from each sample. The results are presented as the total number of virus copies per 250 ng of DNA.

\section{Gene expression by real-time PCR}

RNA isolation and cDNA synthesis

RNA was extracted and purified from head kidney, liver, spleen and gill tissues using the RNeasy Mini Kit (Qiagen) following the manufacturer's instructions, and concentrations were determined by Nanodrop 1000 (Thermo Scientific). RNA was diluted to a standard concentration with diethyl pyrocarbonate (DEPC)-treated water (Invitrogen) and DNase treated (Promega) to remove any trace of remaining genomic DNA. RNA was then transcribed to cDNA using Moloney Murine Leukemia Virus (M-MuLV) Reverse Transcriptase according to the manufacturer's in- 
Table 1. Oligonucleotides used in this study. CyHV-3: cyprinid herpesvirus 3; CRP: C-reactive protein

\begin{tabular}{|c|c|c|c|c|c|}
\hline Gene & Gene function & $\begin{array}{l}\text { Oligo } \\
\text { type }\end{array}$ & Sequence $\left(5^{\prime}-3^{\prime}\right)$ & $\begin{array}{l}\text { GenBank } \\
\text { acc. no. }\end{array}$ & Source \\
\hline KHV-86F & Quantification of & Forward & GAC GCC GGA GAC CTT GTG & AF411803 & Gilad et al. \\
\hline KHV-163R & CyHV-3 DNA & Reverse & CGG GTT CTT ATT TTT GTC CTT GTT & & $(2004)$ \\
\hline KHV-109P & & Probe & $\begin{array}{l}\text { FAM-CTT CCT CTG CTC GGC GAG } \\
\text { CAC G-BHQ1 }\end{array}$ & & \\
\hline ORF72 & $\begin{array}{l}\text { CyHV-3 capsid } \\
\text { triplex protein }\end{array}$ & $\begin{array}{l}\text { Forward } \\
\text { Reverse }\end{array}$ & $\begin{array}{l}\text { GCT TTC TCG ACA CGG AAT GG } \\
\text { GGT TGG CCT CTG TGG ACT TG }\end{array}$ & DQ177346 & $\begin{array}{l}\text { Adamek et } \\
\text { al. }(2012)\end{array}$ \\
\hline $40 S$ & $\begin{array}{l}\text { Housekeeping } \\
\text { gene }\end{array}$ & $\begin{array}{l}\text { Forward } \\
\text { Reverse }\end{array}$ & $\begin{array}{l}\text { CCG TGG GTG ACA TCG TTA CA } \\
\text { TCA GGA CAT TGA ACC TCA CTG TCT }\end{array}$ & AB012087 & $\begin{array}{l}\text { Huttenhuis et } \\
\text { al. (2006) }\end{array}$ \\
\hline $\operatorname{crp} 1$ & CRP response & $\begin{array}{l}\text { Forward } \\
\text { Reverse }\end{array}$ & $\begin{array}{l}\text { AGC AAT GCA ACA TTT TTC CGT C } \\
\text { ACT TGC GTC AAA GCC ACC CAC }\end{array}$ & JQ010977 & $\begin{array}{l}\text { Falco et al. } \\
(2012)\end{array}$ \\
\hline $\operatorname{crp} 2$ & CRP response & $\begin{array}{l}\text { Forward } \\
\text { Reverse }\end{array}$ & $\begin{array}{l}\text { GAT GCT GCA GCA TTT TTC AGT C } \\
\text { CTC CGC ATC AAA GTT GCT CAA AT }\end{array}$ & JQ010978 & $\begin{array}{l}\text { Falco et al. } \\
(2012)\end{array}$ \\
\hline c1rs & $\begin{array}{l}\text { Classical comple- } \\
\text { ment pathway }\end{array}$ & $\begin{array}{l}\text { Forward } \\
\text { Reverse }\end{array}$ & $\begin{array}{l}\text { CAA GCC CAT CTT GGC TCC TGG } \\
\text { GTC CAG ATC AAG CGG GGA CGT }\end{array}$ & AB042609 & $\begin{array}{l}\text { Forlenza et } \\
\text { al. (2009) }\end{array}$ \\
\hline$b f / c 2$ & $\begin{array}{l}\text { Classical and alter- } \\
\text { native comple- } \\
\text { ment pathways }\end{array}$ & $\begin{array}{l}\text { Forward } \\
\text { Reverse }\end{array}$ & $\begin{array}{l}\text { CGG TCA TGG GAA AAA GCA } \\
\text { TTG AGA } \\
\text { GAT ATC TTT AGC ATT TGT CGC AG }\end{array}$ & AB047361 & $\begin{array}{l}\text { Forlenza et } \\
\text { al. (2009) }\end{array}$ \\
\hline$c 3$ & $\begin{array}{l}\text { Central component } \\
\text { of the complement } \\
\text { system; marker of } \\
\text { the } 3 \text { pathways }\end{array}$ & $\begin{array}{l}\text { Forward } \\
\text { Reverse }\end{array}$ & $\begin{array}{l}\text { GGT TAT CAA GGG GAG TTG AGC TAT } \\
\text { TGC TGC TTT GGG TGG ATG GGT }\end{array}$ & AB016215 & $\begin{array}{l}\text { Forlenza et } \\
\text { al. (2009) }\end{array}$ \\
\hline masp2 & $\begin{array}{l}\text { MB-lectine comple- } \\
\text { ment pathway }\end{array}$ & $\begin{array}{l}\text { Forward } \\
\text { Reverse }\end{array}$ & $\begin{array}{l}\text { CAA GCT GTC CAA GGT GAT TG } \\
\text { AGC AGT GAG GAC CCA GTT GT }\end{array}$ & AB234294 & $\begin{array}{l}\text { Forlenza et } \\
\text { al. (2009) }\end{array}$ \\
\hline
\end{tabular}

structions (Invitrogen). Briefly, $0.5 \mu \mathrm{g}$ RNA was added to $0.5 \mathrm{mM}$ dNTPs, $5 \mathrm{mM} \mathrm{MgCl}_{2}, 5 \times$ PCR Buffer II, $1.25 \mu \mathrm{M}$ random hexamers, 20 units of RNase inhibitor, DEPC-treated water and 25 units of M-MuLV and incubated in a GeneAmp ${ }^{\circledR}$ PCR System 9700 thermal cycler (Applied Biosystems) using the following program: $25^{\circ} \mathrm{C}$ for $10 \mathrm{~min}, 42^{\circ} \mathrm{C}$ for $30 \mathrm{~min}$ and $95^{\circ} \mathrm{C}$ for $5 \mathrm{~min}$. CDNA samples were diluted (1:20) in DEPC-treated water before being stored at $-20^{\circ} \mathrm{C}$.

\section{Real-time RT-PCR of APR-related genes}

Real time reverse transcription (RT)-PCR assays were performed using the ABI PRISM ${ }^{\circledR} 7000$ Sequence Detector System (Applied Biosystems). A volume of cDNA corresponding to $10 \mathrm{ng}$ of RNA was added to a final concentration of $900 \mathrm{nM}$ of each primer (Table 1) and $1 \times$ Power SYBR Green PCR Master Mix (Applied Biosystems) in a final volume of $20 \mu \mathrm{l}$. Complement component genes were selected based upon on their functional role and their position in the complement pathways, i.e. $c 1$ rs for the classical, $b f / c 2$ for the classical and alternative, masp2 for the lectin and $c 3$ for its central role in the complement cascade (Gonzalez et al. 2007). Thermal cycling conditions were $2 \mathrm{~min}$ at $50^{\circ} \mathrm{C}$ and $10 \mathrm{~min}$ at $95^{\circ} \mathrm{C}$, followed by 40 cycles of $15 \mathrm{~s}$ at $95^{\circ} \mathrm{C}$ and $1 \mathrm{~min}$ at $60^{\circ} \mathrm{C}$. A melting curve was created for each run and checked to ensure the amplification of a single product. Results were analysed according to the $2^{-\Delta \Delta \mathrm{Ct}}$ method (Livak \& Schmittgen 2001) and normalised against the expression of the $40 \mathrm{~S}$ ribosomal protein S11 reference gene (Huttenhuis et al. 2006). The results are presented as $\mathrm{x}$-fold change in relation to the control treatment.

\section{Real-time RT-qPCR for CyHV-3 capsid triplex protein}

Virus replication was detected based upon mRNA expression of the CyHV-3 capsid triplex protein (CTP) using a plasmid-based quantification RT-qPCR assay as described by Adamek et al. (2012, 2013). A standard plasmid containing the CTP gene was constructed using the method described above for the virus genome plasmid and the primers listed in Table 1. A standard curve ranging from $10^{2}$ to $10^{7}$ gene copies was prepared and used to quantify the copy number of the gene transcripts in each sample. qPCR assays for each sample were performed using a StepOnePlus thermal cycler (Applied Biosystems). Each reaction contained cDNA corresponding to a volume of $10 \mathrm{ng}$ of RNA, $200 \mathrm{nM}$ of each primer 
(Table 1), 1× Power SYBR Green PCR Master Mix in a total volume of $20 \mu \mathrm{l}$. Samples were analysed using the following thermal profile: polymerase activation at $50^{\circ} \mathrm{C}$ for $2 \mathrm{~min}$, initial denaturation at $95^{\circ} \mathrm{C}$ for $10 \mathrm{~min}, 40$ cycles of denaturation at $95^{\circ} \mathrm{C}$ for $30 \mathrm{~s}$, annealing at $60^{\circ} \mathrm{C}$ for $30 \mathrm{~s}$ and elongation at $72^{\circ} \mathrm{C}$ for $30 \mathrm{~s}$ (Adamek et al. 2013). The expression levels of the CyHV-3 CTP gene are presented as the gene copy number normalised for $1 \times 10^{5}$ copies of the gene encoding for the $40 \mathrm{~S}$ ribosomal protein S11 (normalised copy number) using the following equation: Normalised copy number $=$ mRNA copy number of the CyHV-3 CTP gene / (mRNA copy number of 40S ribosomal protein $\mathrm{S} 11 / 1 \times 10^{5}$ ).

Confirmation of positive results was performed by comparison against a melting curve generated during each PCR run.

\section{Statistical analysis}

All data are given as means \pm SEM of 4 or 5 independent individuals. Statistical analysis was carried out using GraphPad Prism v5 and PASW Statistics 18 software. Data were tested for normality and homoscedasticity prior to further analysis. A 2-way analysis of variance (ANOVA) and post hoc Bonferroni multiple comparisons test were performed on serum cCRP levels and complement activity to determine significant differences between the infected and the control groups. Gene expression data were normalised using a log-transformation prior to a 2-way ANOVA and subsequent Bonferroni post hoc test analysis. In order to investigate whether serum cCRP levels and serum complement ACP activity were correlated, Pearson correlation analyses were performed. Additional post hoc Pearson correlation analyses were performed to investigate whether variations observed in serum levels or activities were correlated to specific related gene expression. Significance was defined as $\mathrm{p} \leq 0.05$.

\section{RESULTS}

\section{Course of infection}

CyHV-3 DNA was detected as early as $24 \mathrm{hpi}$ in the spleen (Fig. 1) and then in all analysed tissues from 72 hpi. The highest virus loads for each organ were recorded at $120 \mathrm{hpi}$ with 9187, 61 766, and 435252 copies per $250 \mathrm{ng}$ of DNA isolated from liver, spleen and gill tissues, respectively. Although significant

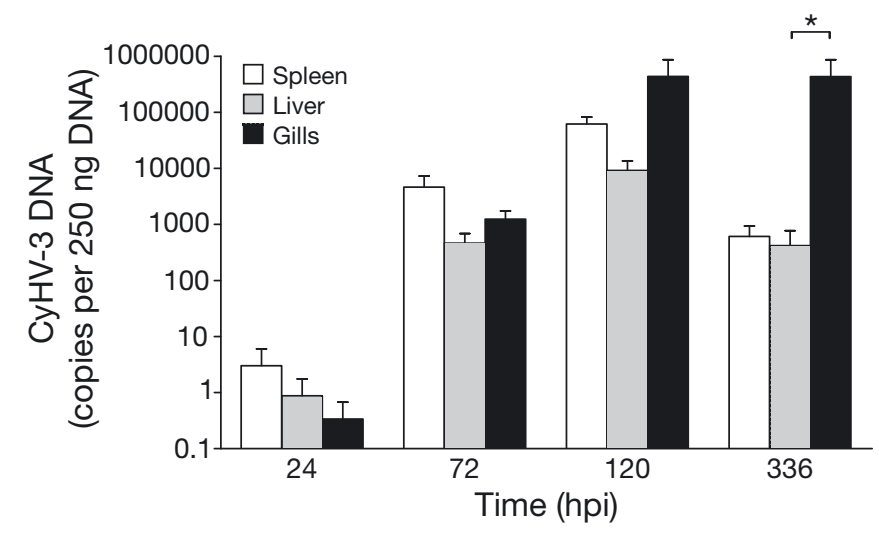

Fig. 1. Cyprinus carpio. Cyprinid herpesvirus 3 (CyHV-3) load in the spleen (white bars), liver (gray bars) and gill (black bars) tissues of carp measured by TaqMan qPCR. Data are means + SEM genome copies for $250 \mathrm{ng}$ of isolated DNA for $n=5$ fish per time point. ${ }^{*}$ Significant difference $(p \leq 0.05)$

differences were not noted between organs at 24, 72 and $120 \mathrm{hpi}$, the viral loads were significantly higher in the gills compared to the liver $(\mathrm{p}<0.05)$ at $336 \mathrm{hpi}$ (432789 and 418 copies, respectively). Viral DNA was not detected in control fish.

The presence of CyHV-3 CTP mRNA expression was first seen at $72 \mathrm{hpi}$ in the spleen in infected fish (Table 2). The highest expression levels were recorded in all tissues at $120 \mathrm{hpi}$ (150 normalised copies in the gills, 210 normalised copies in the head kidney, 260 normalised copies the liver and 1270 normalised copies in the spleen). Virus replication also occurred at $336 \mathrm{hpi}$ in the head kidney. Viral mRNA was not found to be expressed in control fish.

\section{Serum acute phase proteins profiles}

Serum cCRP levels (Fig. 2A) were significantly different between control and infected groups $(F=$

Table 2. Cyprinus carpio. Cyprinid herpesvirus 3 (CyHV-3) capsid triplex protein (CTP) mRNA expression in the liver, head kidney, spleen and gills measured at 24, 72, 120 and $336 \mathrm{~h}$ post infection (hpi). Data are mean copy numbers ( \pm SEM, $n=5$ ) of the CyHV-3 CTP gene normalised against 100000 copies of $40 \mathrm{~S}$ ribosomal protein S11. No Ct: CyHV-3 CTP mRNA was not detected

\begin{tabular}{|c|c|c|c|c|}
\hline \multirow{2}{*}{$\begin{array}{l}\text { Time } \\
\text { (hpi) }\end{array}$} & \multicolumn{4}{|c|}{ Normalised copy number in tissue } \\
\hline & Liver & Head kidney & Spleen & Gill \\
\hline 24 & No Ct & No Ct & No Ct & No Ct \\
\hline 72 & $\mathrm{No} C t$ & $\mathrm{No} C t$ & $3.3 \pm 2$ & No Ct \\
\hline 120 & $147.2 \pm 83$ & $210.6 \pm 95$ & $1267 \pm 370$ & $147.2 \pm 83$ \\
\hline 336 & No Ct & $29.6 \pm 26$ & No Ct & No Ct \\
\hline
\end{tabular}




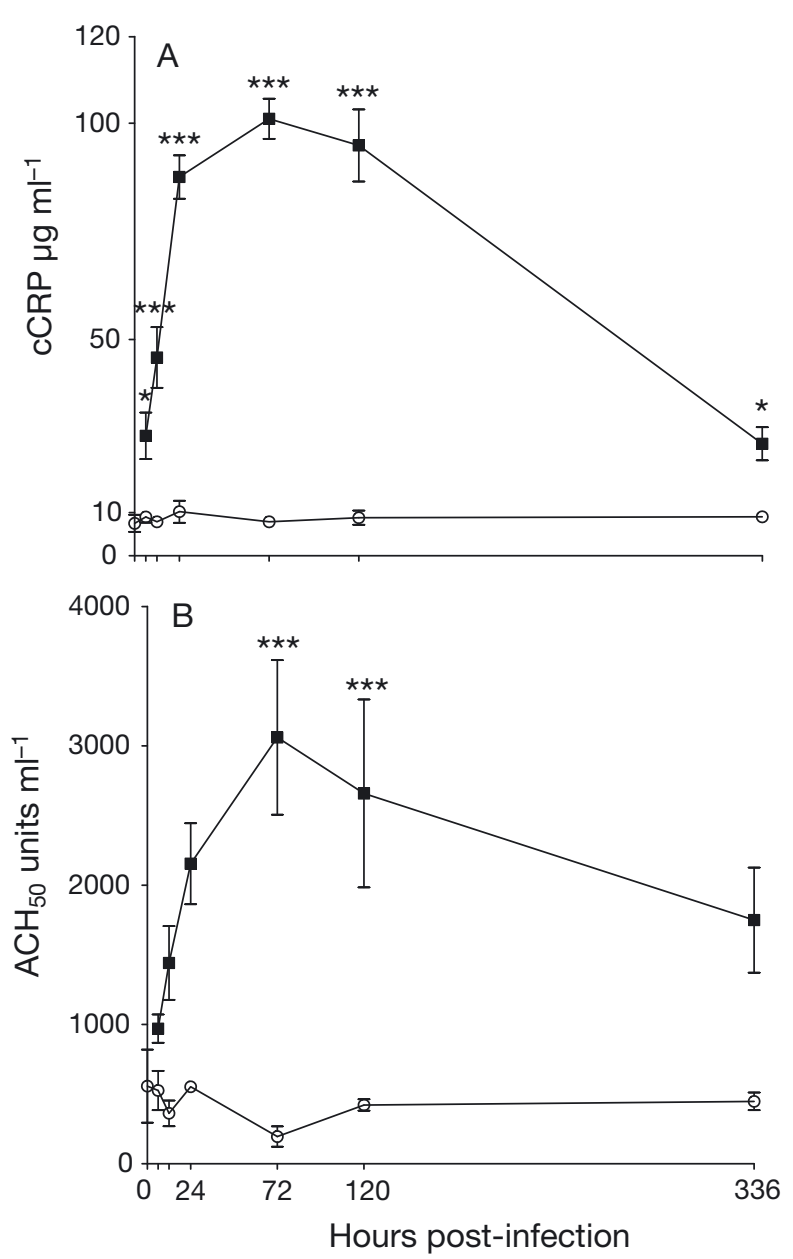

Fig. 2. Cyprinus carpio. (A) C-reactive protein (CRP) levels and (B) alternative complement pathway (ACP) activity in the serum of carp infected with cyprinid herpesvirus 3 $(\mathrm{CyHV}-3)$ by bath immersion. Data are means \pm SEM $(\mathrm{n}=4$ or 5). Statistical significance as determined by Bonferroni post hoc 2-way ANOVA when comparing data from infected fish (ם) to those obtained from the control fish $(O)$ at their respective sampling points indicated as follows: ${ }^{*} \mathrm{p}<0.05$, ${ }^{* *} \mathrm{p}<0.01,{ }^{* * *} \mathrm{p}<0.001$

629.6, df $=1, \mathrm{p}<0.0001$ ), over time since treatment $(F=30.7, \mathrm{df}=6, \mathrm{p}<0.0001)$, and also when time/ treatment interactions were considered $(F=31.0, \mathrm{df}=$ $6, \mathrm{p}<0.0001)$. A Bonferroni post hoc analysis revealed that serum cCRP levels were significantly higher in the infected fish compared to control fish during the whole duration of the challenge. Indeed, whilst CCRP levels in control fish were constantly below $10 \mu \mathrm{g} \mathrm{ml}^{-1}$, cCRP levels in infected carp were already significantly increased by $6 \mathrm{hpi}\left(27.8 \mu \mathrm{g} \mathrm{ml} \mathrm{m}^{-1}, \mathrm{p} \leq\right.$ $0.05)$ and reached a plateau from $24 \mathrm{hpi}\left(87.6 \mu \mathrm{g} \mathrm{ml}^{-1}\right.$, $\mathrm{p} \leq 0.001)$ until $120 \mathrm{hpi}\left(95 \mu \mathrm{g} \mathrm{ml} \mathrm{m}^{-1}, \mathrm{p} \leq 0.001\right)$ after which a decrease occurred at $336 \mathrm{hpi}\left(25.9 \mu \mathrm{g} \mathrm{ml}^{-1}\right.$, $\mathrm{p} \leq 0.05)$.
Serum ACP activity (Fig. 2B) was abolished by heat inactivation and was also significantly different between control and infected groups $(F=59.9$, df $=1$, $\mathrm{p}<0.0001)$. Although the duration of infection did not appear to have an effect $(F=2.0$, df $=6, \mathrm{p}=$ $0.0864)$, the time/treatment interaction was significantly affected $(F=2.7, \mathrm{df}=6, \mathrm{p}=0.0316)$. A Bonferroni post hoc analysis revealed that the serum ACP activity was significantly higher in infected fish at 72 hpi (3060 $\mathrm{ACH}_{50}$ units $\mathrm{ml}^{-1}, \mathrm{p} \leq 0.001$ ) and $120 \mathrm{hpi}$ (2658 $\mathrm{ACH}_{50}$ units $\mathrm{ml}^{-1}, \mathrm{p} \leq 0.001$ ) whilst the ACP activity in control fish remained stable at these sampling points (approximately $500 \mathrm{ACH}_{50}$ units $\mathrm{ml}^{-1}$ ). It is interesting to note that, as with serum cCRP levels, serum ACP activity increased in infected fish from 6 hpi onwards and reached a plateau between 72 and 120 hpi before it finally decreased at the end of the challenge (336 hpi).

Pearson correlation statistical analyses revealed that CRP levels and complement activity were not correlated in control fish but were significantly positively correlated in infected fish $(\mathrm{r}=0.6996, \mathrm{p}<$ 0.0001), indicating complement ACP activity and CRP levels both increasing at the same time in those carp.

\section{CRP- and complement-related gene expression profiles}

The constitutive expression levels of CRP (crp1 and crp2) and complement (c1rs, bf/c2, c3 and masp2) genes in the control group (Table 3) clearly indicated that all of the analysed genes were synthesised in the liver. Except for $\operatorname{crp} 2$ and $b f / c 2$, the threshold cycle $(\mathrm{Ct})$ values were lower in the liver compared to the other tissues. It is interesting to note, however, that extra-hepatic expression was also clearly noticeable for $b f / c 2$ in the head kidney, spleen and gill tissues, suggesting a wide expression of this $b f / c 2$ gene.

In the liver (Fig. 3A), all genes except crp1 were up-regulated in response to CyHV-3 infection ( $F=$ 7.2-30, df $=1, \mathrm{p} \leq 0.0117$ ). Time also significantly affected the expression of all genes analysed $(F=$ 4.6-11.7, $\mathrm{df}=3, \mathrm{p} \leq 0.0086)$, except for masp2 $(F=2.7$, $\mathrm{df}=3, \mathrm{p}=0.0647$ ).

Interestingly, post hoc analysis revealed that the CyHV-3 infection caused several significant downregulations for the expression of crp1 at $24 \mathrm{hpi}$ (0.1-fold, $\mathrm{p} \leq 0.01)$, 72 hpi (0.26-fold, $\mathrm{p} \leq 0.01)$ and 120 hpi $(0.12$-fold, $\mathrm{p} \leq 0.01)$ except for a significant up-regulation at 336 hpi (2.3-fold, p $\leq 0.05)$. Although 
Table 3. Cyprinus carpio. Ct values of C-reactive protein (CRP; $\operatorname{crp} 1$ and $\operatorname{crp} 2)$ and complement $(c 1 r s, b f / c 2, c 3$ and masp2) gene expression levels from the control group in the different tissues. Significant differences when comparing the $\mathrm{Ct}$ values from the liver to those from the other organs are indicated as follows: ${ }^{* *} \mathrm{p} \leq 0.01,{ }^{* * *} \mathrm{p} \leq 0.001$. Data are means $\pm \operatorname{SEM}(\mathrm{n}=5)$

\begin{tabular}{|c|c|c|c|c|}
\hline \multirow[t]{2}{*}{ Gene } & \multicolumn{4}{|c|}{$\mathrm{Ct}$ value in tissue } \\
\hline & Liver & Head kidney & Spleen & Gill \\
\hline crp1 & $24.7 \pm 0.3$ & $34.2 \pm 0.2^{* * *}$ & $33.3 \pm 0.1^{* * *}$ & $35.4 \pm 0.6^{* * *}$ \\
\hline $\operatorname{crp} 2$ & $35.6 \pm 0.3$ & $31.7 \pm 0.4^{* * *}$ & $34.5 \pm 0.4$ & $31 \pm 0.4^{* * *}$ \\
\hline c1rs & $23.5 \pm 0.6$ & $31.4 \pm 0.3^{* * *}$ & $30.8 \pm 0.2^{* * *}$ & $31.9 \pm 0.2^{* * *}$ \\
\hline$b f / c 2$ & $27.9 \pm 0.5$ & $24.5 \pm 0.4^{* * *}$ & $26.6 \pm 0.3$ & $30 \pm 0.3^{* *}$ \\
\hline c3 & $19.2 \pm 0.3$ & $35.6 \pm 0.8^{* * *}$ & $30.5 \pm 0.2^{* * *}$ & $32.3 \pm 0.5^{* * *}$ \\
\hline masp2 & $24.4 \pm 0.4$ & $36.7 \pm 0.3^{* * *}$ & $37.3 \pm 0.2^{* * *}$ & $37.6 \pm 0.4^{* * *}$ \\
\hline
\end{tabular}

crp2 expression was also up-regulated (6.4-fold, $\mathrm{p} \leq$ 0.01 ) at $336 \mathrm{hpi}$, in contrast to $\operatorname{crp} 1$, there was also an increase at 72 hpi (3.6-fold, p $\leq 0.05)$. In addition, a pattern of significant up-regulations was also shown for complement-related gene expression at $72 \mathrm{hpi}$, i.e. 4.9-fold for $c 1 r s$ ( $\mathrm{p} \leq 0.01)$, 8.2-fold for $b f / c 2$ ( $\mathrm{p} \leq$ 0.001), 5.8-fold for $c 3(\mathrm{p} \leq 0.001)$ and 2.8-fold for masp2 ( $\mathrm{p} \leq 0.05)$. Significant up-regulations were also detected at $120 \mathrm{hpi}$ for $b f / c 2$ (8.1-fold, p $\leq 0.001$ ) and $c 3$ (3.4-fold, p $\leq 0.01)$, and at $336 \mathrm{hpi}$ for $c 1$ rs (4.1-fold, $\mathrm{p} \leq 0.05)$, and a significant down-regulation was observed at $24 \mathrm{hpi}$ for c1rs expression (0.12-fold, $\mathrm{p} \leq 0.05)$.

In contrast to the liver, viral infection significantly affected the gene expression of $c 3$, masp 2 and crp 1 in the head kidney (Fig. 3B) $(F=5.8-8.7$, df $=1, \mathrm{p} \leq$ $0.022)$ but not the expression of $c 1 r s, b f / c 2$ and $c r p 2$ $(F=1.3-3.37$, df $=1, \mathrm{p} \geq 0.0756)$. With the exception of $c 1 r s$ and masp2 $(F=1.6, \mathrm{df}=3, \mathrm{p}=0.2047$ and $F=$ 2.3 , df $=3, p=0.0957$, respectively), duration of infection significantly affected CRP- and complementrelated gene expression $(F=3.262-8.303$, df $=3$, p $\leq$ 0.0341).

Post hoc analysis revealed a significant upregulation of crp1 at $336 \mathrm{hpi}$ in the head kidney (6.3-fold, $\mathrm{p} \leq 0.01)$ similar to the one observed in the liver, although down-regulations were not detected at the early sampling points. Interestingly, crp2 expression was significantly affected by the duration of the infection with up-regulation detected at $24 \mathrm{hpi}(1.8$-fold, $\mathrm{p} \leq 0.05)$ followed by a subsequent down-regulation at 72 and $336 \mathrm{hpi}$ (0.33- and 0.25-fold, respectively, $p \leq 0.05$ ). As with the liver, a pattern of significant up-regulation of complement-related gene expression was detected in the head kidney at $72 \mathrm{hpi}$ for $\mathrm{bf} / \mathrm{c} 2$ (2.35-fold, p $\leq 0.001), c 3$ (25.74-fold, p $\leq 0.001$ ) and masp2 (5-fold, $\mathrm{p} \leq 0.05)$. Finally, the fourth com- plement-related gene analysed, c1rs, was significantly up-regulated at 336 hpi (2.9-fold, p $\leq 0.05)$.

In the spleen (Fig. 3C), expression of $b f / c 2, c 3, c r p 1$ and $\operatorname{crp} 2$ was significantly affected by CyHV-3 infection $(F=6.5-29.6, \mathrm{df}=1, \mathrm{p} \leq 0.016)$ but not the expression of $c 1 r s$ and masp2 $(F=$ 1.6, $\mathrm{df}=1, \mathrm{p}=0.2183$ and $F=0.01$, $\mathrm{df}=1, \mathrm{p}=0.9201$, respectively). As in the liver and head kidney, expression of the 2 CRP-related genes was significantly affected by time $(F=3.5$, $\mathrm{df}=3, \mathrm{p}=0.0275$ for $\operatorname{crp} 1$ and $F=3.9$, $\mathrm{df}=3, \mathrm{p}=0.0169$ for $\operatorname{crp} 2$ ). However, for the complement-related genes, duration of infection only affected the expression of $b f / c 2(F=7.9, \mathrm{df}=$ $3, \mathrm{p}=0.0004)$.

Post hoc analysis revealed significant up-regulations in CRP-related gene expression, i.e. up-regulation of crp1 at 120 hpi (3.2-fold, p $\leq 0.01)$ and upregulations of $\operatorname{crp} 2$ at 24 hpi $(3.4$-fold, $\mathrm{p} \leq 0.01)$ and 336 hpi (3.3-fold, $\mathrm{p} \leq 0.01)$. Regarding complementrelated genes, the expression profiles of c1rs and masp2 were not significantly affected during the duration of the challenge whilst the expression of $b f / c 2$ was substantially up-regulated at 72 hpi (12.4fold, $\mathrm{p} \leq 0.001)$ and 120 hpi (8.5-fold, p $\leq 0.01)$ and upregulation was detected in $c 3$ expression at $336 \mathrm{hpi}$ (8.2-fold, $\mathrm{p} \leq 0.01$ ).

Finally, in the gills (Fig. 3D), the expression of all genes analysed was significantly affected by the viral infection $(F=4.8-25$, df $=1, \mathrm{p} \leq 0.0364)$, with the exception of $c 3(F=1.6, \mathrm{df}=1, \mathrm{p}=0.2111)$. In contrast to the head kidney and liver, the effect of duration of infection was found to be significant only for $\mathrm{bf} / \mathrm{c} 2$ $(F=4.6, \mathrm{df}=3, \mathrm{p}=0.0087)$ and $\operatorname{crp} 2(F=9.3, \mathrm{df}=3, \mathrm{p}=$ $0.0001)$ expression.

Interestingly, post hoc analysis revealed that crp1 expression was not affected by the infection in the gills, but a pattern of up- and down-regulation of crp2 expression was detected, i.e. up-regulation at 24 hpi (3.5-fold, p $\leq 0.001)$, then down-regulation at 72 and 120 hpi $(0.3$-fold, p $\leq 0.01$ and 0.36 -fold, $\mathrm{p} \leq 0.05$ respectively), and finally up-regulation at 336 hpi (2.7-fold, p $\leq 0.05)$. Regarding complementrelated genes, whilst the expression of $c 3$ and masp2 were not significantly affected during the challenge period, c1rs was significantly up-regulated at $120 \mathrm{hpi}$ (2.2-fold, $\mathrm{p} \leq 0.05$ ) and $b f / c 2$ was significantly upregulated at 24 hpi (3.1-fold, p $\leq 0.05), 72$ hpi (7.8fold, $\mathrm{p} \leq 0.05), 120 \mathrm{hpi}(7.6$-fold, $\mathrm{p} \leq 0.01)$ and $336 \mathrm{hpi}$ (20.7-fold up-regulation, $\mathrm{p} \leq 0.001$ ). 


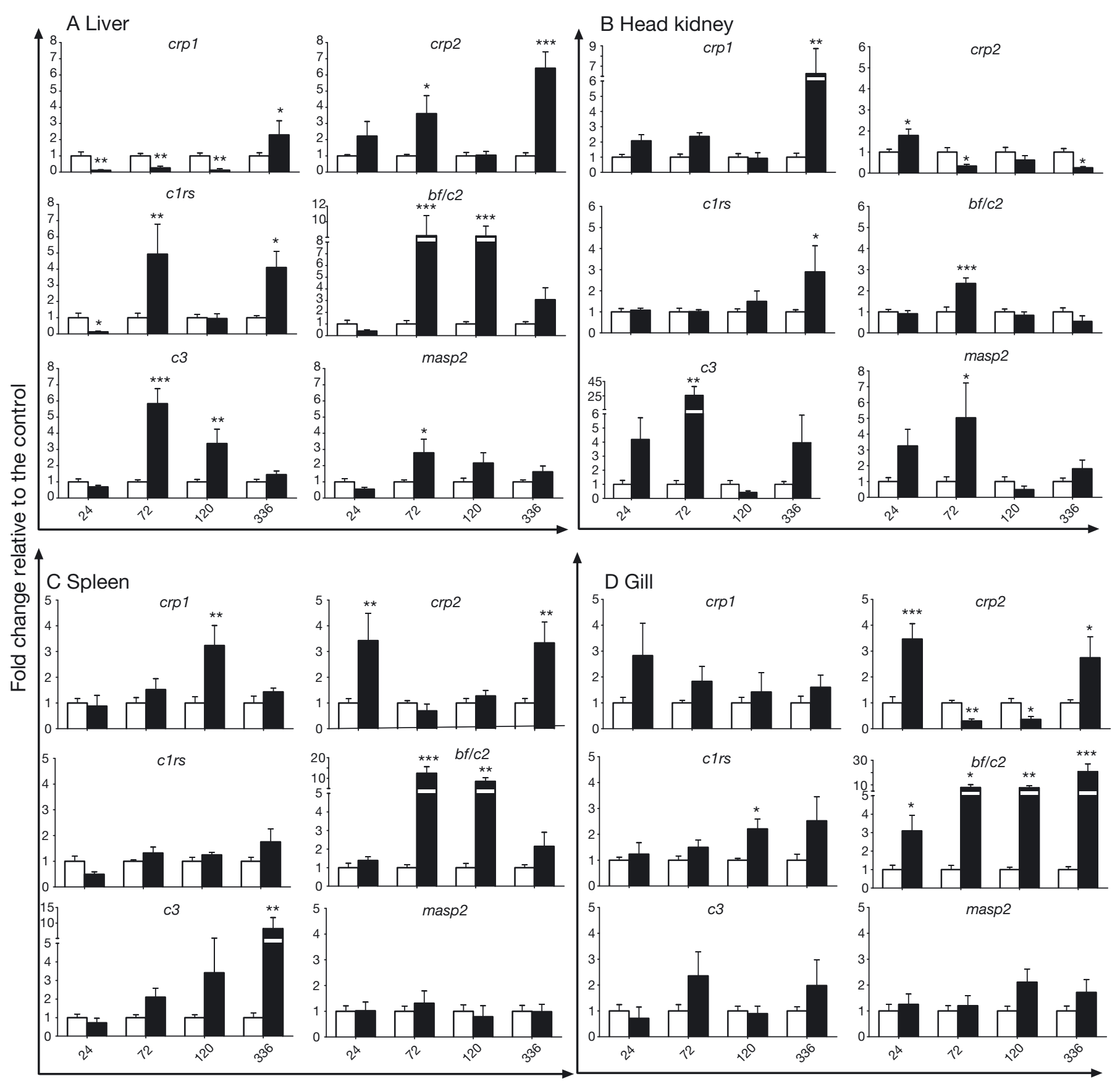

Hours post-infection

Fig. 3. Cyprinus carpio. C-reactive protein (CRP; crp1 and crp2) and complement (c1rs, bf/c2, c3 and masp2) related gene transcript profiles in (A) liver, (B) head kidney, (C) spleen and (D) gills of carp infected with cyprinid herpesvirus 3 (CyHV-3) by bath immersion. Expression levels of the infected groups (black bars) are shown as $\mathrm{x}$-fold change compared to the control group (white bars) at each time point. Significant differences when comparing the infected groups to their respective time point control group are indicated as follows: ${ }^{*} \mathrm{p} \leq 0.05,{ }^{* *} \mathrm{p} \leq 0.01,{ }^{* * *} \mathrm{p} \leq 0.001$. All data are means $\pm \operatorname{SEM}(\mathrm{n}=5)$

\section{DISCUSSION}

The present study reveals that both CRP and complement responses, monitored by either serum activity/ levels or gene expression in tissues, significantly changed in common carp challenged with CyHV-3 by bath infection. Although a viral load was noted at $24 \mathrm{hpi}$, a significant increase in viral DNA occurred after $72 \mathrm{hpi}$ in all the tissues analysed (spleen, liver and gills). In addition, significant increases in serum CRP levels and complement activity were recorded during the first $72 \mathrm{hpi}$ in the infected carp, indicating 
a strong and rapid immune acute phase response in these fish. Interestingly, although we noted the absence of viral gene expression at $336 \mathrm{hpi}$, Adamek et al. (2013) suggested that this may occur after this period of infection.

The rapid and significant increase in serum cCRP levels (from $6 \mathrm{hpi}$ to a 10-fold increase in $72 \mathrm{~h}$ ) has revealed for the first time that CRP behaves as a positive acute phase reactant in common carp challenged with $\mathrm{CyHV}-3$. This immediate response is remarkable, since at this point, no pathological changes were recorded. The promptly elevated levels of serum CCRP that reach a maximum between 72 and $120 \mathrm{hpi}$ may be related to the systemic character of the infection and therefore could support the putative role of CCRP in the induction of the leukocytosis as observed by Negenborn (2009). In addition, the viral load and replication as recorded in all tissues analysed at 72 and 120 hpi combined with previous results from Rakus et al. (2012) and Adamek et al. (2013) indicate that the virus spreads throughout the whole body, reaching multiple organs within $72 \mathrm{~h}$ after pathogen exposure. This leads to significant up-regulations in the synthesis of several immune-related genes at $72 \mathrm{hpi}$, including genes involved in the regulation of CRP expression (Szalai et al. 2000) such as IL-6, IL$1 \alpha$, IL-1 $\beta$, TNF- $\alpha$ and C3 and C5a complement components (Rakus et al. 2012). Furthermore, a significant increase in the classical pathway complement activity and in the expression of its related genes (c1rs and bf/c2) at 120 hpi may contribute to cCRP activation.

Interestingly, these elevated levels of serum cCRP do not appear to be correlated with CRP-related gene expression profiles when considering all tissues analysed, in particular the liver. Results revealed different patterns in all tissues examined; for example, levels of crp1 were decreased in liver, but were enhanced in spleen and kidney. In contrast, crp2 gene expression was reduced in head kidney but elevated in liver and spleen. However, due to the substantial difference in crp1 and crp2 Ct values in the liver of control fish (i.e. a 1024-fold difference in expression), the amount of CRP1 mRNA produced in infected fish was still significantly higher than the amount of CRP2 mRNA even if there was a 0.12 -fold reduction in $\operatorname{crp} 1$ and a 6 -fold up-regulation of crp2. Previous studies also suggested that additional CRP-related genes might code for different common carp CRP isoforms (Falco et al. 2012, Pionnier et al. 2013). As the rabbit anti-cCRP IgG used to detect CRP levels in the carp serum reacts with native carp CRP, this could explain the differences observed between cCRP serum levels and tissue-related gene expression. In addition, the antibody used in this study reacts with native carp CRP, but we do not know yet if CRP is encoded predominantly by crp1 or crp2. These results suggest an organ- and timedependent response which could be due to different biological and functional properties of the synthesised proteins in the different tissues as hypothesised by Falco et al. (2012). However, it is interesting to note that $\operatorname{crp} 1$ and $\operatorname{crp} 2$ have been found to be expressed constitutively in a mucosal site (gills) as well as in systemic sites (spleen, head kidney and liver), thus confirming the widespread CRP expression in a range of tissues in carp reported by Falco et al. (2012). The observation that CyHV-3 infection had a significant effect on cCRP-related gene expression in the gills may be particularly noteworthy, as gills are severely affected by the virus (Perelberg et al. 2003), and the highest viral loads were detected in the gills. Despite the fact that, in mammals, increasing serum CRP levels are more characteristic of a bacterial infection rather than a viral infection (Cray et al. 2009), primarily mediated through the direct binding of CRP to phosphocholine residues of bacterial C-polysaccharides (Volanakis \& Kaplan 1971), our results suggest that the CRP response may also be of great importance during viral infections in carp. In that case, CRP, as an acute phase reactant, could play a role in the general activation of other acute phase immune components such as the complement system as observed, for example, in mammals (Agrawal et al. 2001) and in the late recognition and clearance of apoptotic, damaged or necrotic cells (Hack et al. 1997). The former is in accordance with simultaneously enhanced mRNA levels of apoptosis-inducing genes during the CyHV-3 infection (J. J. Miest et al. unpubl.), which indicate induced apoptosis at $120 \mathrm{hpi}$.

CyHV-3 infection also induced a complement response in carp, which was inactivated by heat treatment, and resulted in a 6 -fold increase in serum ACP activity beginning at 6 hpi and reaching a maximum of approximately $3000 \mathrm{ACH}_{50}$ units ml $\mathrm{ml}^{-1}$ between 72 and $120 \mathrm{hpi}$. This is in accordance with the results obtained for the ACP-related gene expression profiles (i.e. $b f / c 2$ and $c 3$ ). Indeed, significant up-regulations of $b f / c 2$ were detected throughout the challenge in the 4 tissues examined, with substantial up-regulations occurring at 72 and 120 hpi, e.g. around 8-fold in the liver and in the gills, and up to 12.4-fold in the spleen. Such significant up-regulations of $b f / c 2$ were also found by Forlenza et al. (2009) in the hepatopancreas of common carp challenged with the parasite Trypanoplasma borreli. The results of our study indicate that CyHV-3 infection significantly induced the 
production of $\mathrm{Bf} / \mathrm{C} 2$ in a variety of systemic sites, i.e. spleen, liver and head kidney, but also at a possible site of infection, i.e. gills, suggesting that the complement alternative pathway was stimulated in response to the virus. However, the literature on the relationship between complement-related gene expression and virus infection in fish is inconsistent. Whilst some studies have shown that neutralisation of some fish viruses such as the infectious haematopoeitic necrosis virus (IHNV) and the viral haemorrhagic septicaemia virus (VHSV) are complement-independent in several fish species (LaPatra 1996, Boshra et al. 2006), other investigations have revealed that the hosts' immune responses could be complement-dependent (LaPatra 1996, Lorenzen \& LaPatra 1999). According to Ellis (2001), this could depend on the virus type, i.e. if the virus possesses an envelope, the complement system will be activated and if not, no changes would be detected in complement response. As CyHV-3 possesses an envelope, our results would support this theory. The expression profile of the other complementrelated gene analysed, viz. $c 3$, which is also involved in the $\mathrm{ACP}$, revealed a significant up-regulation in the head kidney, liver and spleen. The up-regulation of the $c 3$ gene detected in the head kidney (25-fold) and in the liver (6-fold) at $72 \mathrm{hpi} \mathrm{could} \mathrm{be} \mathrm{related} \mathrm{to} \mathrm{a} \mathrm{need}$ for $\mathrm{C} 3$ production in order to maintain the complement activity at a high level. Such $c 3$ up-regulations in response to virus infection in fish were also observed in the Japanese flounder Paralichthys olivaceus challenged with VHSV (Byon et al. 2006) and in rainbow trout Oncorhynchus mykiss challenged with IHNV (Overturf \& LaPatra 2006). Finally, up-regulation (from 2- to 5-fold) of the genes encoding c1rs and masp 2 occurred in the head kidney, liver and gills but not in the spleen. This suggests that the classical and lectin complement pathways could have been stimulated, potentially through CRP, although no significant increase was detected in the serum complement classical pathway activity of those carp (Rakus et al. 2012). The fact that the expression of these classical and lectin pathway-related genes (c1rs and masp2, respectively) were less affected than the expression of the alternative pathway-related genes ( $b f / c 2$ and $c 3$ ) is in agreement with previous studies suggesting that the alternative pathway has a greater role than the classical or the lectin pathways in fish immune response to viral and bacterial infections (Yano 1996, Ellis 2001, Boshra et al. 2006).

In carp, the acute phase response to CyHV-3 infection has also been found to be organ dependent. The increase in CRP and complement responses could be related to different tissue damages observed, for in- stance, in the gills, kidney, spleen and liver of carp infected by CyHV-3 (Perelberg et al. 2003). Our results are in accordance with other studies performed on the same individual fish, revealing that the expression of several immune-related genes was affected in the head kidney and spleen (Rakus et al. 2012), and that the regulation of apoptosis-related genes was also organ- and time-dependent (J. J. Miest et al. unpubl.). In our study, gene expression of CRP- and complement-related genes was especially affected at 72 and $120 \mathrm{hpi}$ in the head kidney and liver. However, these effects were less prominent in the gills and spleen. These observations are supported by Pearson correlation analyses, which revealed significant correlations between serum cCRP levels and crp1 and crp2 gene expression but only in the liver of infected fish $(\mathrm{r}=$ $0.28, p=0.0007$ and $r=0.48, p=0.047$, respectively). Despite the fact that teleost complement components and CRP have been found to be primarily expressed in the liver (Boshra et al. 2006, Nakao et al. 2011), our results are in accordance with those obtained in previous studies performed on common carp (Falco et al. 2012, Pionnier et al. 2013) and also in cod Gadus morhua (Lange et al. 2004a) and halibut Hippoglossus hippoglossus (Lange et al. 2004b), suggesting a widespread tissue distribution of complement and CRP in fish as observed in mammals (Sahu et al. 1998). Nevertheless, statistical analyses revealed the greatest infection and time effects in the liver, where the expression of 5 of the 6 genes analysed was significantly affected by either the infection or the duration of the infection, highlighting the importance of the liver in acute phase reactant production in carp. Interestingly, data analysis also revealed that the expression of some CRP- and complement-related genes in the gill tissue was significantly affected by the infection with, for example, up to 20-fold up-regulation of $\mathrm{bf} / \mathrm{c} 2$ and both and up- and down-regulation in crp2. These results indicate that the gills may be an important mucosal site involved in the carp immune APR as suggested in previous studies (Perelberg et al. 2003, Dishon et al. 2005).

In summary, an acute phase immune response has been identified in common carp infected by CyHV-3 via a bath immersion route. This stimulation, i.e. increased serum CCRP levels and ACP activity and upregulation of complement- and CRP-related genes in analysed immune organs, has shown that these 2 innate protein systems, i.e. CRP and complement, behave as typical acute phase reactants to a viral infection in carp. Hence it could be possible to use CRP and complement as immediate biomarkers to detect infections in fish as it is used in humans. 
Acknowledgements. We thank T. Greenhough, A. Shrive, J. Cartwright and E. MacCarthy for their previous achievements on carp CRP isolation, extraction and purification as well as for the supply of rabbit polyclonal anti-cCRP IgG. The research leading to these results received funding from the European Community's Seventh Framework Programme (FP7/2007-2013 under grant agreement no. PITNGA-2008-214505).

\section{LITERATURE CITED}

Adamek M, Rakus KL, Chyb J, Brogden G, Huebner A, Irnazarow I, Steinhagen D (2012) Interferon type I responses to virus infections in carp cells: in vitro studies on Cyprinid herpesvirus 3 and Rhabdovirus carpio infections. Fish Shellfish Immunol 33:482-493

> Adamek M, Syakuri H, Harris S, Rakus KŁ and others (2013) Cyprinid herpesvirus 3 infection disrupts the skin barrier of common carp (Cyprinus carpio L.). Vet Microbiol 162: $456-470$

Adkison MA, Gilad O, Hedrick RP (2005) An enzyme-linked immunosorbent assay (ELISA) for detection of antibodies to the koi herpesvirus (KHV) in the serum of koi Cyprinus carpio. Fish Pathol 40:53-62

Agrawal A, Shrive AK, Greenhough TJ, Volanakis JE (2001) Topology and structure of the C1q-binding site on C-reactive protein. J Immunol 166:3998-4004

Bayne CJ, Gerwick L (2001) The acute phase response and innate immunity of fish. Dev Comp Immunol 25:725-743

Białowąs H, Irnazarow I, Rakus K, Jurecka P, Pilarczyk A (2008) Carp breeds of Poland. Ministry of Agriculture of the Russian Federation, Moscow

Boshra H, Li J, Sunyer JO (2006) Recent advances on the complement system of teleost fish. Fish Shellfish Immunol 20:239-262

Bretzinger A, Fischer-Scherl T, Oumouna M, Hoffmann R, Truyen U (1999) Mass mortalities in Koi carp, Cyprinus carpio, associated with gill and skin disease. Bull Eur Assoc Fish Pathol 19:182-185

> Byon JY, Ohira T, Hirono I, Aoki T (2006) Comparative immune responses in Japanese flounder, Paralichthys olivaceus after vaccination with viral hemorrhagic septicemia virus (VHSV) recombinant glycoprotein and DNA vaccine using a microarray analysis. Vaccine 24:921-930

- Cartwright JR, Tharia HA, Burns I, Shrive AK, Hoole D, Greenhough TJ (2004) Isolation and characterization of pentraxin-like serum proteins from the common carp Cyprinus carpio. Dev Comp Immunol 28:113-125

- Costalonga EC, Melo NC, Rodrigues CE, Sette LH, Ianhez LE (2009) The potential role of C-reactive protein in distinguishing cytomegalovirus from tuberculosis and bacterial infections in renal transplant recipients. Clin Transplant 23:710-715

> Costes B, Raj VS, Michel B, Fournier G and others (2009) The major portal of entry of koi herpesvirus in Cyprinus carpio is the skin. J Virol 83:2819-2830

> Crane M, Hyatt A (2011) Viruses of fish: an overview of significant pathogens. Viruses 3:2025-2046

> Cray C, Zaias J, Altman NH (2009) Acute phase response in animals: a review. Comp Med 59:517-526

Davison AJ, Eberle R, Ehlers B, Hayward GS and others (2009) The order Herpesvirales. Arch Virol 154:171-177

> Davison AJ, Kurobe T, Gatherer D, Cunningham C and others (2013) Comparative genomics of carp herpes- viruses. J Virol 87:2908-2922

> Dishon A, Perelberg A, Bishara-Shieban J, Ilouze M, Davidovich M, Werker S, Kotler M (2005) Detection of carp interstitial nephritis and gill necrosis virus in fish droppings. Appl Environ Microbiol 71:7285-7291

Dixon PF, Joiner CL, Way K, Reese RA, Jeney G, Jeney Z (2009) Comparison of the resistance of selected families of common carp, Cyprinus carpio (L.), to koi herpesvirus: preliminary study. J Fish Dis 32:1035-1039

> Dumrongphol Y, Hirota T, Kondo H, Aoki T, Hirono I (2009) Identification of novel genes in Japanese flounder (Paralichthys olivaceus) head kidney up-regulated after vaccination with Streptococcus iniae formalin-killed cells. Fish Shellfish Immunol 26:197-200

> Ellis AE (2001) Innate host defence mechanisms of fish against viruses and bacteria. Dev Comp Immunol 25: 827-839

Encinas P, Rodriguez-Milla MA, Novoa B, Estepa A, Figueras A, Coll J (2010) Zebrafish fin immune responses during high mortality infections with viral haemorrhagic septicemia rhabdovirus. A proteomic and transcriptomic approach. BMC Genomics 11:518

> Falco A, Cartwright JR, Wiegertjes GF, Hoole D (2012) Molecular characterization and expression analysis of two new C-reactive protein genes from common carp (Cyprinus carpio). Dev Comp Immunol 37:127-138

Forlenza M, Nakao M, Wibowo I, Joerink M, Arts JA, Savelkoul HF, Wiegertjes GF (2009) Nitric oxide hinders antibody clearance from the surface of Trypanoplasma borreli and increases susceptibility to complementmediated lysis. Mol Immunol 46:3188-3197

Fournier G, Boutier M, Stalin Raj V, Mast J and others (2012) Feeding Cyprinus carpio with infectious materials mediates cyprinid herpesvirus 3 entry through infection of pharyngeal periodontal mucosa. Vet Res 43:6

Gilad O, Yun S, Zagmutt-Vergara FJ, Leutenegger CM, Bercovier H, Hedrick RP (2004) Concentrations of a Koi herpesvirus (KHV) in tissues of experimentally-infected Cyprinus carpio koi as assessed by real-time TaqMan PCR. Dis Aquat Org 60:179-187

- Gonzalez SF, Buchmann K, Nielsen ME (2007) Complement expression in common carp (Cyprinus carpio L.) during infection with Ichthyophthirius multifiliis. Dev Comp Immunol 31:576-586

Goodwin A (2003) Differential diagnosis: SVC vs. KHV in koi. Fish Health Newsl 31:9-13

> Gruys E, Toussaint MJ, Niewold TA, Koopmans SJ (2005) Acute phase reaction and acute phase proteins. J Zhejiang Univ Sci B 6:1045-1056

> Hack CE, Wolbink GJ, Schalkwijk C, Speijer H, Hermens WT, van den Bosch H (1997) A role for secretory A2 and C-reactive protein in the removal of injured cells. Immunol Today 18:111-115

Haenen OLM, Way K, Bergmann SM, Ariel E (2004) The emergence of koi herpesvirus and its significance to European aquaculture. Bull Eur Assoc Fish Pathol 24: 293-307

Hedrick RP, Gilad O, Yun S, Spangenberg JV and others (2000) A herpesvirus associated with mass mortality of juvenile and adult koi, a strain of common carp. J Aquat Anim Health 12:44-57

Huttenhuis HBT, Taverne-Thiele AJ, Grou CPO, Bergsma J, Saeij JP, Nakayasu C, Rombout JH (2006) Ontogeny of the common carp (Cyprinus carpio L.) innate immune system. Dev Comp Immunol 30:557-574 
Lange S, Dodds AW, Magnadóttir B (2004a) Isolation and characterization of complement component C3 from Atlantic cod (Gadus morhua L.) and Atlantic halibut (Hippoglossus hippoglossus L.). Fish Shellfish Immunol 16:227-239

Lange S, Bambir S, Dodds AW, Magnadóttir B (2004b) An immunohistochemical study on complement component C3 in juvenile Atlantic halibut (Hippoglossus hippoglossus L.). Dev Comp Immunol 28:593-601

> LaPatra SE (1996) The use of serological techniques for virus surveillance and certification of finfish. Annu Rev Fish Dis 6:15-28

> Livak KJ, Schmittgen TD (2001) Analysis of relative gene expression data using real time quantitative PCR and the $2^{-\Delta \Delta C_{\mathrm{T}}}$ method. Methods 25:402-408

> Lorenzen N, LaPatra SE (1999) Immunity to rhabdoviruses in rainbow trout: the antibody response. Fish Shellfish Immunol 9:345-360

MacCarthy EM, Burns I, Irnazarow I, Polwart A, Greenhough TJ, Shrive AK, Hoole D (2008) Serum CRP-like protein profile in common carp Cyprinus carpio challenged with Aeromonas hydrophila and Escherichia coli lipopolysaccharide. Dev Comp Immunol 32:1281-1289

- Matsuyama H, Tanaka K, Nakao M, Yano T (1988) Characterization of the alternative complement pathway of carp. Dev Comp Immunol 12:403-408

Michel B, Leroy V, Stalin Raj V, Lieffrig F and others (2010) The genome of cyprinid herpesvirus 3 encodes 40 proteins incorporated in mature virions. J Gen Virol 91:452-462

Mohanty BR, Sahoo PK (2010) Immune responses and expression profiles of some immune-related genes in Indian major carp, Labeo rohita to Edwardsiella tarda infection. Fish Shellfish Immunol 28:613-621

Nakao M, Tsujikura M, Ichiki S, Vo TK, Somamoto T (2011) The complement system in teleost fish: progress of posthomolog-hunting researches. Dev Comp Immunol 35: 1296-1308

Negenborn J (2009) Klinisch-chemische Parameter im Blut und Urin von Karpfen unter Infektion mit dem Koi-herpesvirus. PhD thesis, University of Veterinary Medicine in Hannover

Neukirch M, Bottcher K, Bunnajirakul S (1999) Isolation of a virus from koi with altered gills. Bull Eur Assoc Fish Pathol 19:221-222

Overturf K, LaPatra S (2006) Quantitative expression (Walbaum) [sic] of immunological factors in rainbow trout, Oncorhynchus mykiss (Walbaum), after infection with either Flavobacterium psychrophilum, Aeromonas salmonicida, or infectious haematopoietic necrosis virus. J Fish Dis 29:215-224

> Pepys MB, Dash AC, Fletcher TC, Richardson N, Munn EA, Feinstein A (1978) Analogues in other mammals and in fish of human plasma proteins C-reactive protein and amyloid P component. Nature 273:168-170

Perelberg A, Smirnov M, Hutoran M, Diamant A, Bejerano Y, Kotler M (2003) Epidemiological description of a new viral disease afflicting cultured Cyprinus carpio in Israel. Isr J Aquacult 55:5-12

Pionnier N, Falco A, Miest J, Frost P, Irnazarow I, Shrive A, Hoole D (2013) Dietary $\beta$-glucan stimulate complement and C-reactive protein acute phase responses in common carp (Cyprinus carpio) during an Aeromonas salmonicida infection. Fish Shellfish Immunol 34:819-831
Pokorova D, Vesely T, Piackova V, Reschova S, Hulova J (2005) Current knowledge on koi herpesvirus (KHV): a review. Vet Med-Czech 50:139-147

Raj VS, Fournier G, Rakus K, Ronsmans M and others (2011) Skin mucus of Cyprinus carpio inhibits cyprinid herpesvirus 3 binding to epidermal cells. Vet Res 42:92

Rakus K, Wiegertjes G, Adamek M, Siwicki A, Lepa A, Irnazarow I (2009) Resistance of common carp (Cyprinus carpio L.) to cyprinid herpesvirus-3 is influenced by major histocompatibility (MH) class II B gene polymorphism. Fish Shellfish Immunol 26:737-743

> Rakus K, Irnazarow I, Adamek M, Palmeira L and others (2012) Gene expression analysis of common carp (Cyprinus carpio L.) lines during Cyprinid herpesvirus 3 infection yields insights into differential immune responses. Dev Comp Immunol 37:65-76

Ramos F, Smith A (1978) The C-reactive protein (CRP) test for the detection of early disease in fishes. Aquaculture 14:261-266

Reed LJ, Muench HA (1938) A simple method of estimating fifty percent endpoints. Am J Hyg 24:493-497

Sahu A, Sunyer JO, Moore WT, Sarrias MR, Soulika AM, Lambris JD (1998) Structure, functions, and evolution of the third complement component and viral molecular mimicry. Immunol Res 17:109-121

Selvaraj V, Sampath K, Sekar V (2005) Administration of yeast glucan enhances survival and some non-specific and specific immune parameters in carp (Cyprinus carpio) infected with Aeromonas hydrophila. Fish Shellfish Immunol 19:293-306

Selvaraj V, Sampath K, Sekar V (2006) Adjuvant and immunostimulatory effects of $\beta$-glucan administration in combination with lipopolysaccharide enhances survival and some immune parameters in carp challenged with Aeromonas hydrophila. Vet Immunol Immunopathol 114: $15-24$

> Szalai AJ, Bly JE, Clem LW (1994) Changes in serum concentrations of channel catfish (Ictalurus punctatus Rafinesque) phosphorylcholine-reactive protein (PRP) in response to inflammatory agents, low-temperature shock and infection by the fungus Saprolegnia sp. Fish Shellfish Immunol 4:323-336

Szalai AJ, van Ginkel FW, Wang Y, McGhee JR, Volanakis JE (2000) Complement-dependent acute phase expression of C-reactive protein and serum amyloid P component. J Immunol 165:1030-1035

Volanakis JE, Kaplan MH (1971) Specificity of C-reactive protein for choline phosphate residues of pneumococcal C-polysaccharide (35323). Proc Soc Exp Biol Med 136: 612-614

Yano T (1996) The nonspecific immune system: humoral defence. In: Iwama G, Nakanishi $T$ (eds) The fish immune system: organism, pathogen and environment. Academic Press, San Diego, CA, p 105-157

> Yano T, Hatayama Y, Matsuyama H, Nakao M (1988) Titration of alternative complement pathway activity of representative cultured fishes. Bull Jpn Soc Sci Fish 54: 1049-1054

Yasuike M, Kondo H, Hirono I, Aoki T (2007) Difference in Japanese flounder, Paralichthys olivaceus gene expression profile following hirame rhabdovirus (HIRRV) G and $\mathrm{N}$ protein DNA vaccination. Fish Shellfish Immunol 23: $531-541$

Submitted: July 8, 2013; Accepted: January 28, 2014

Proofs received from author(s): May 19, 2014 